\title{
ON THE QUESTION OF PRIORITY OF HOMER AND HESIOD
}

\begin{abstract}
Hesiod's listeners or readers could have better understood his references to the creation of Pandora and to the character of women in general if they had previously known Homer's poetry. The present argument supports the view that the epics of Homer preceded those of Hesiod.
\end{abstract}

I

It has been argued that the real problem in discussing the chronological order of Homer and Hesiod lies mainly in our "methods» and "criteria"1. Several passages and contexts" indicate some kind of borrowing or influence, and the matter has been further complicated by the analytic methods applied to each poet separately in an attempt to distinguish in his work the "old" from the "new" or the agenuine" from the "spurious".

It makes good sense to propose that the disputed passages be interpreted in the light of the poet's own "style" and "thought" and that their contexts be also taken into consideration ${ }^{3}$, but dispute can arise about these matters. Poetic contexts are certainly important, but they are often motivated by purposes which are not always easy to identify. Consequently, we may not be able to establish the priority of a certain passage over another. I would propose an examination of major thematic elements with particular reference to the manner in which they are introduced into the poem, and I will presently confine

1 Cf. H. Neitzel, Homer-Rezeption bei Hesiod (Abhandlungen zur Kunst-Musikund Literaturwissenschaft, Bd. 189), Bonn 1975, p. 1 ff., esp. p. 14 and passim.

2 Relevant material and bibliography in Neitzel's book.

3 Neitzel puts emphasis on this approach which has been suggested by others (cf. F. Kraft, Vergleichende Untersuchungen zu Homer und Hesiod [Hypomnemata 6], Göttingen 1963, p. 85), and explores its potential more fully. He comes to the conclusion that Hesiod depends upon Homer. 
my discussion to Hesiod's treatment of women which is best illustrated by the Pandora-myth.

Some think that Hesiod was an anti-feminist ${ }^{4}$. It has been pointed out that the poet was deeply concerned with the economics and politics of his days and that, reflecting the worries and troubles of the average Boeotian peasant, he viewed women as a necessity but at the same time as a bad economic liability, owing to their vices and also to the fact that women had no concrete stake in any particular social or political order, and hence his hostility towards them ${ }^{5}$. According to another view Hesiod derived his ideas about women from the East ${ }^{6}$.

It is true that Hesiod lived in a time when cultural contacts were reestablished with the Orient ${ }^{7}$ and that the hard realities of his days influenced his work, but Hesiod was, above all, writing poetry, not sociology. This means that he was open to literary influences and stimulations as well. His audience too would look forward to listening to his poetry and not to an account of their daily chores and troubles. There existed poetic competitions ${ }^{8}$. The significance of this fact is fully explored and utilized in the present argument. Such competitions sharpened the wits of the audience and provided a pool of information about traditional and contemporary poetry.

The Pandora-myth (Works and Days 57-101, Theogony 570-590) should reflect some of the poet's own ideas about women, but there are

4 Yet cf. F. Brenk, «Hesiod: How much a Male Chauvinist?», $C B 49,1973$, p. $73 \mathrm{ff}$.

5 Cf. Sarah B. Pomeroy, Goddesses, Whores, Wives and Slaves, New York 1975 , p. $48 \mathrm{f}$., and, in more details, Marylin B. Arthur, "Early Greece: The Origins of the Western Attitude Toward Women", Arethusa 6, 1973, p. $24 \mathrm{ff}$.

6 Cf. F. A. Wright, Feminism in Greek Literature, N. Y. 1923, p. $16 \mathrm{ff}$., quoted with approval by T. A. Sinclair, Hesiod Work and Days, Hildesheim 1966 (Repr.), Introd., p. xxxii. Wright does not elaborate; occasionally he vaguely speaks of Oriental influence. Cf. also W. Erdmann, Die Ehe im alten Griechenland (Münchener Beiträge zur Papyrusforschung und antiken Rechtsgeschichte, Heft 20), München 1934 , p. 13, n. 5. J. Vogt, «Von der Gleichwertigkeit der Geschlechter in der bürgerlichen Gesellschaft der Griechen», Ak. d. Wiss. u. d. Lit. Abh. d. Geistes- $u$. sozialwiss. Klasse, Wiesbaden 1960 , Nr. 2, p. 216, points out that the treatment of women in the Orient was consistently bad and that in early times influence was not at work though Greece and the Orient had maintained contacts. Yet it should not be overlooked that prior to the Dorian conquest the matriarchal element was strong in the Greek and Oriental societies. In this context cf. Annemarie Jenzer, Wandlungen in der Auffassung der Frau im ionischen Epos und in der Tragödie bis auf Sophokles, Zürich 1933, p. $6 \mathrm{ff}$.

7 In this context cf. C. G. Starr, The Origins of Greek Civilization, London 1962, pp. $192 \mathrm{ff}$. and $221 \mathrm{ff}$.

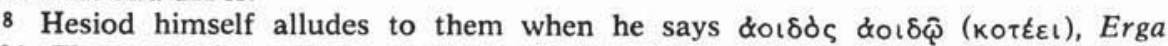
25-26. The poet also tells us that he took in a competition at the funeral games of Amphidamas at Chalkis (Erga $650 \mathrm{ff}$.). On the nature, time and circumstances

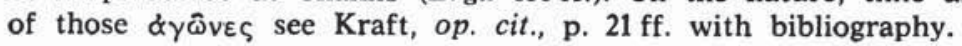


some relevant passages in his work which should also be taken into consideration. What concerns us here is not the myth and its symbolism ${ }^{9}$ but the attributes and qualities which the poet ascribes to Pandora and also the way in which he presents the divinities that contribute to her creation. There should be little doubt that Hesiod was familiar with an "old folktale" and that the theme of "women's extravagance and ill-nature" is known the world over ${ }^{10}$, but it is the treatment of the theme that makes all the difference.

In Hesiod it is Zeus who first speaks of Pandora in terms of an evil (к๔кóv) in which men will rejoice (Erga 57f.). The poet might or might not have had unpleasant experiences with women ${ }^{11}$; he might or might not have heard accounts of the first woman. But in the Odyssey we

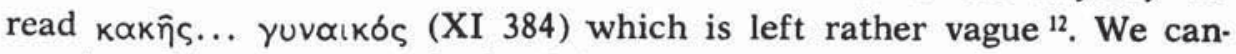
not date this passage or the book in which it occurs, and for the present purpose it may not be very important whether women or some women were considered "evil" in literature before Hesiod. There is however another, more important, consideration.

Hephaestus is ordered to make a creature and to endow her with

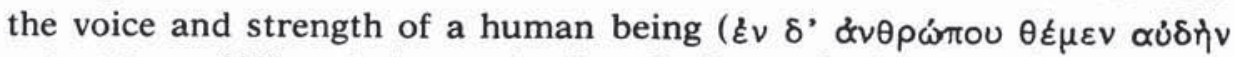
$\kappa \propto l i \theta \varepsilon v \circ \varsigma, 61 f$.) and also to give her the form of a lovely maiden, resembling the very gods (62-63). But these references to the skills of the god presuppose some knowledge on the part of the listeners. For the poet does not explain why it is Hephaestus who gets the special job of mixing water and earth to make the creature. The poet obviously assumes that his listeners knew that Hephaestus was a maker, and all that is now needed is to find the source or sources of the listeners' knowledge of the functions of the god. Let it also be noted that this is not the only passage that assumes familiarity, on the part of the listener, with traditional sources and poetry.

We look in vain for this kind of information in Hesiod's own work. In Theogony 571f. the god is even introduced without his personal name:

9 On the subject in general see esp. G. S. Kirk, Myth, its Meaning and Function in Ancient and other Cultures, Cambridge 1971, p. $235 \mathrm{ff}$.; P. Diel, Symbolism in Grcek Mythology, London 1980, p. 209 ff.; O. Lendle, Die «Pandorasage» bei Hesiod, Würzburg 1957, p. $58 \mathrm{ff}$.

10 Cf. G. S. Kirk, The Nature of Greek myths, Harmonsdworth, Middlesex, 1974 , p. $140 \mathrm{ff}$.

11 Lendle, op. cit., p. 87, thinks that Hesiod speaks from his own experience.

12 The poet may mean Helen or Clytemnestra. Cf. W. B. Stanford, Homer Odyssey, I, p. 384. 


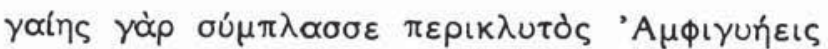

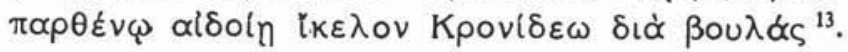

West comments: "The fashioning of a figure from clay is naturally (italics mine) attributed to a potters' god, here Hephaestus...» ${ }^{14}$. But "naturally" can only stand on the assumption that Hesiod's listeners knew about the god's functions as we do. How else could they understand this activity of the god?

Even when the poet comes to speak about the god's family tree (vv. 927-929), there is no explanatory reference to this important function of the god; only a vague hint:

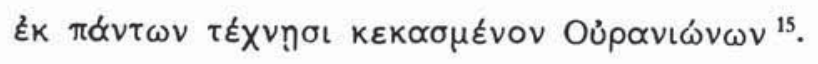

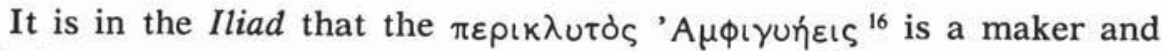
a builder. In I 607f. he built the divine dwellings ${ }^{17}$. In II 101 he made Agamemnon's sceptre, in XVIII 239-241 a special chair for Hera, and in vv. 478ff. Achilles' arms. But the most important passage is of course XVIII $417 \mathrm{ff}$. where reference is made to the golden servant girls which worked for Hephaestus and which he fashioned ${ }^{18}$, giving them $\alpha u \dot{\delta} \delta \dot{\eta}$ $\kappa \alpha l \sigma \theta \dot{\varepsilon} v \circ \varsigma^{19}$.

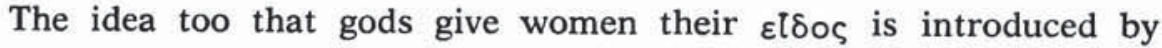
Hesiod, in the above context, on the assumption that his audience are familiar with this function of the gods, and though we do not know all sources of this kind of information, we know, for a fact, that the Homeric epics contain it ${ }^{20}$.

Hephaestus is not the only god whose skills and functions are taken for granted by the poet ${ }^{21}$. The same is true of the other gods who par-

13 Cf. also Erga, 70-71.

14 M. L. West, Hesiod Theogony, Oxford 1966, p. 326. West, who believes that Homer comes after Hesiod (p. $46 \mathrm{f}$. For criticism of his views see G. P. Edwards, The Language of Hesiod in its Traditional Context, Oxford 1971, p. $203 \mathrm{ff}$.$) , says$ in his work Hesiod Works \& Days, Oxford 1978, that v. 61f. "appear to have influenced Homer's description of another creation of Hephaestus, his golden girl-robots» (p. 158).

15 Note however that he made a golden wreath for Pandora (Theog. $579 \mathrm{f}$.).

16 Cf. Il. I 607, XIV 239, XVIII 383, etc. Cf. also Od. VIII 300, 349, etc.

17 Note too that in Il. I $571 \mathrm{ff}$. the god is properly introduced.

18 Cf. West, op. cit., p. 326.

19 Notice these words in Hesiod's account (Erga $61 \mathrm{f}$.), and cf. further $\theta \varepsilon \circ 0$

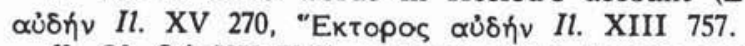

20 Cf. Od. XX $70 \mathrm{ff}$. and my study, Nature and Background of Major Concepts

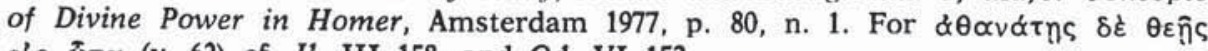
Els $\bar{\omega} \pi \alpha$ (v. 62) cf. Il. III 158, and Od. VI 152.

${ }_{21}$ It should be noted that the cult of Hephaestus was very old. Cf. L. R. Farnell, Cults of the Greek States, Oxford 1909, V, p. $374 \mathrm{ff}$. 
ticipate in the creation of Pandora. Athene, we are told, should teach Pandora ${ }^{22}$ needlework and weaving (63f.):

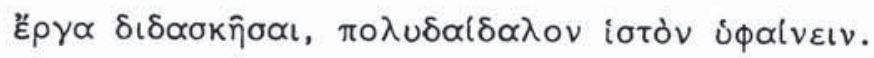

But this task presupposes that Athene was known to possess and to impart these skills to women. Elsewhere Hesiod only stresses the goddess' warlike nature (Theog. 924ff.) and he refers to her as $\gamma \lambda \propto u \kappa \hat{\omega} \pi \iota \varsigma$ (Th. 573, Erga 72) ${ }^{23}$. It is in Homer that we again find the complete information about Athene's handicraft skills (Od. XX 72) ${ }^{24}$ :

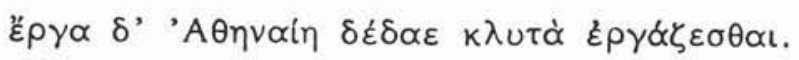

The goddess, we are told, taught the daughters of Pandareus the erga, and there are more references to this quality of Athene (Il. IX 390, Od. VII 111, XIII 289 etc.): she is skilled at handicrafts and teaches women.

Athene was worshipped as $\varepsilon \rho \gamma \alpha \alpha v \eta^{25}$, and though we cannot date the beginnings of the cult ${ }^{26}$, we can safely connect it with the com-

22 Cf. also West, op. cit., p. 159. On $\delta เ \delta \alpha \sigma \kappa \eta ̂ \sigma \alpha \iota$ see Neitzel's comments (op. cit., $28 \mathrm{ff}$.). He thinks that the idea of teaching is not appropriate in view of the fact that Pandora is supposed to be a $k \propto \kappa \delta v$ or a $\pi \hat{\eta} \mu \alpha$ and that weaving does not agree with the character qualities ascribed to Pandora in Erga 67-68. His comments are illuminating but I am not convinced by his argument. A woman's abilities need not be in conflict with her character. Helen, for example, is an excellent weaver

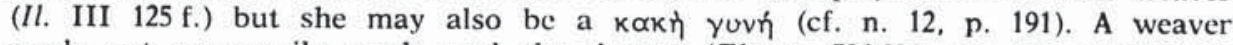
needs not necessarily work, and the drones (Theog. $594 \mathrm{ff}$.) are not necessarily ignorant and incapable by nature; they simply do not work. Pandora's other divine gifts might interfere with her handicraft abilities, but this is another question. Zeus is not totally unfair to man. The god does not give man a beautiful but stupid woman, though the danger is there that her good qualities might be destroyed by the "bad" ones. V. 72 is not a "statt dessen". We are not told that Zeus canceled his orders to Athene; nor should we expect more details on this point.

${ }^{23}$ It should be noted that Athene is a war goddess of wise counsel in Homer (cf. my study, op. cit., p. $46 \mathrm{ff}$.) and her cult was probably much older. Cf. M. Ventris-J. Chadwick, Documents in Mycenaean Greek, Cambridge 1956, p. 126, for a-ta-na po-ti-ni-ja KN $208=\mathrm{V} 52$.

24 Note that the verse occurs in a passage (vv. 66-82) which is bracketed by some editors (cf. Stanford, Odyssey, II, p. 344). West, op. cit., p. 158 f., apparently considers it genuine.

25 For the testimonies see my study, op. cit., p. 53, n. 33.

26 According to Pausanias (I 24) the title $\varepsilon \rho y \alpha u \eta$ was given to Athene by the Athenians, and Horace (Carm. III 12, 5) renders it by operosa Minerua. Hesiod calls the plough maker a servant of Athene (Erga 450), but already in the Iliad XV $410 \mathrm{ff}$., the carpenter derives his skills from Athene. In the Hymn to Aphrodite, which is dated about 700 B. C. (cf. A. Athanassakis, The Homeric Hymns, Baltimore 1976, p. 92), Athene taught the carpenters but also women (cf. vv. 12-15): 
mercial rise of Athens sometime in the sixth century. Even if the cult were older it probably did not supply listeners of Hesiod with the kind of information which would facilitate an understanding of his references to the goddess in the creation myth ${ }^{27}$. The real source of information should be the Homeric epics which were recited at festivals and on other occasions ${ }^{28}$.

The Homeric gods endow man with physical qualities as indicated above, but also with various skills. The poet says about Hephaestus' girl servants (Il. XVIII 420):

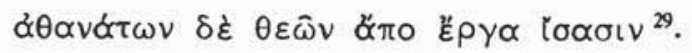

Aphrodite is another major goddess who participates in the creation of Pandora. She sees to it that Pandora is given grace, longing and cares (65f.):

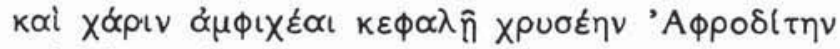

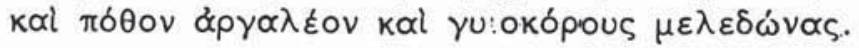

Even the elaborate account of the goddess' nature in the Theogony 191-206, was not sufficient for Hesiod's audience to fully understand the function ascribed to her in the above passage. Her spheres of influence (vv. 203-206) do not include giving lovely gifts to mortals. Did the poet assume that his listeners were familiar with this aspect of the goddess's power?

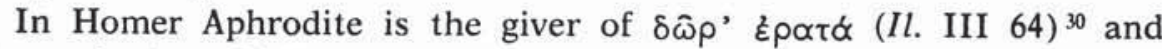
Hera asks her (Il. XIV 198f.):

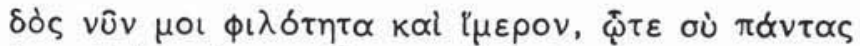

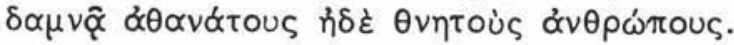

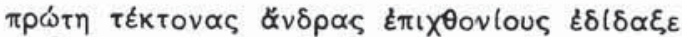

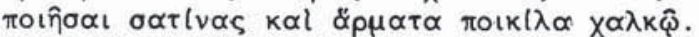

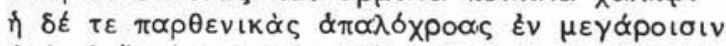

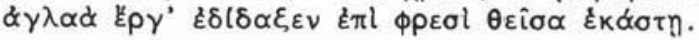

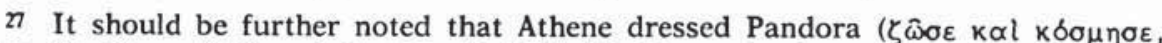
Erga 72, Theog. 573), and that in Il. XIV 178 Athene is the maker of the garment which Hera puts on. Following Robert, Hermes 49, 1914, p. 29, Kraft, op. cit., p. 102, rightly understands this part of Athene's involvement in terms of an «instruction» (Unterricht).

28 In this context see Kraft, op. cit., p. 21, with bibliography.

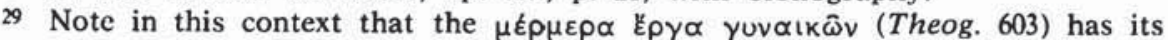

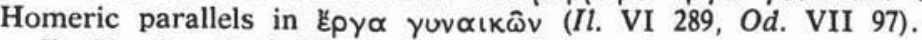

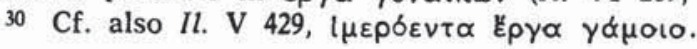


Hesiod's $\pi \delta \theta 0 \nu$ replaces $\phi 1 \lambda \delta \tau \eta \tau \alpha \kappa \propto l$ i $\mu \varepsilon \rho o \nu$, and the idea of his $\gamma \cup$ :okópous $\mu \varepsilon \lambda \varepsilon \delta \omega v \alpha \varsigma$ is expressed by $\delta \alpha \mu v \hat{\alpha}$. On the other hand,

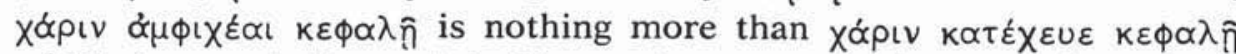
which is repeatedly used in Homer in passages where people are miraculously transformed by the gods ${ }^{31}$.

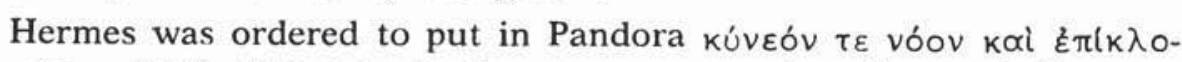
$\pi \circ v \bar{\gamma} \theta \circ \varsigma$ ( $67 \mathrm{f}$.). This introduction too assumes that the poet's listeners were familiar with the god's powers and functions. But Hesiod's work does not provide the complete information. In Theog. 444 Hermes appears as a herdsman $\operatorname{god}^{32}$ and in v. 939 (Erg. 80) as a divine herald (кńpuk' $\left.\alpha^{2} \theta \alpha v \alpha \tau \omega \nu\right)^{33}$. There is nothing here about the activity of the god which the above words describe. The background of this activity may be found in Homer. Hermes has the power to coze the mind (II.

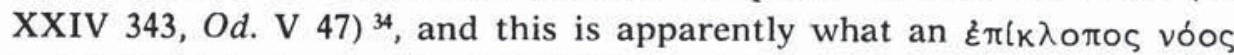
is supposed to do. In Od. XI 364-366 an $\varepsilon \pi\left(\kappa \lambda \circ \pi \circ \varsigma\right.$ tells lies $(\psi \varepsilon \dot{\delta} \delta \varepsilon \alpha)^{35}$ which amounts to deceiving. As a matter of fact in v. 78 we read that in addition to the $\varepsilon \pi(\kappa \lambda$ o $\pi \circ \nu \bar{\eta} \theta \circ \varsigma$ Hermes gives Pandora, at the request

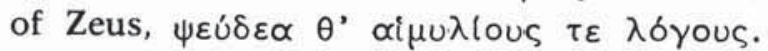

We do not know if Hesiod or his audience knew the Hermes źpıoú$v$ in (Il. XX 34, 360 etc.) and how they understood this attribute which grammarians and lexicographers explained in terms of $k \lambda \varepsilon \dot{\varepsilon} \pi \eta S^{36}$. Certain Homeric contexts present Hermes as a thief or as a patron of thieves. In Il. XXIV 24 the gods urge him to go and steal the body of Hector, and in Od. XIX 396f. Hermes endowed Autolycus with the talents of thievery and perjury ${ }^{37}$. The Hymn to Hermes contains an elaborate account of this aspect of the god's nature, and though we cannot date the Hymn there is reason to assume that it comes after the Homeric epics ${ }^{38}$.

As for the kúveov vóov, the Homeric epics provide sufficient information. The locus classicus is of course Od. XI 424-428, which belongs

\footnotetext{
31 Cf. for example Od. VI 235, VIII 20, XXIII 162.

32 Cf. also Hymn to Hermes, and West, op. cit., p. 289.

33 West comments, p. 416, «Hermes is not described by any corresponding phra-

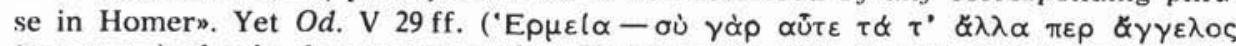
$\varepsilon \sigma \sigma i k \tau \lambda$.) clearly demonstrates that Hermes was "the herald of the immortalsn.

34 However, other gods too have the same power. Cf. Il. XII 255, XIII 435.

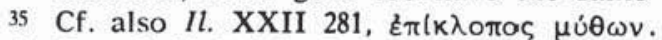

36 Yet cf. H. Frisk, Griech. etym. Wörterbuch, I, p. 559.

37 On ґркщ, v. 396, see Stanford's illuminating comments (Odyssey, II, p. 332).

38 Cf. Athanassakis, op. cit., p. 87, who thinks that this portrayal of Hermes "is not an innovation by the composer of the hymn" and quotes Homer. Athanassakis would place its date "somewhere in the middle of the seventh century».
} 
to a section of the poem considered by some to be late, but already in the Iliad Helen calls herself a woman with a dog's mind (II. III 180) ${ }^{39}$.

Even minor divinities, such as Charites, are introduced in a way that is best understood in the light of some foreknowledge of them. Charites, and Peitho, put oppous xpuoclous on Pandora (73f.). In Theog. 64 the Charites dwell on Olympus, in v. 907 they are named and in v. 910 their eyes can excite desire. But they do not appear as givers of any kind of $\delta \hat{\omega} p \alpha$. In Homer however they can groom a person (Od. VIII 364ff.) and they also gave Aphrodite her peplos which they made for her (Il. V 338).

It has been indicated above that there might have been a number of sources which influenced Hesiod. His language shows that he was familiar with "dialect sources" ${ }^{40}$, and there should be little doubt that some hexameter poetry existed on the mainland. Hesiod might have known local compositions about the great Olympians who were traditional gods ${ }^{41}$. Yet Herodot's statement (II 53) that it was Homer and Hesiod who gave the Greeks their gods throws light on an important point: no other poet or poets from that period spoke to the people about the gods with reverential authority. If we therefore find that Hesiod presupposes some knowledge about the gods on the part of his listeners, it can only be that both he and his listeners learned about the gods from the source par excellence, i.e. the Homeric epics.

Hesiod, on the other hand, was not writing solely for a local audience; the range of poetry which a local audience could understand should be very limited indeed. Hesiod's participation in competitions abroad (Erga 65ff.) indicates that he wanted to make his poetry known elsewhere, and possibly everywhere, in the Greek world. He should therefore be expected to give it a panhellenic appeal, which he could best achieve along the lines of the Homeric epics. The tradition too that he competed with Homer indicates that he only rivaled the poet par excellence, whatever his borrowings from other sources might have been. If «it was the prestige of the Homeric epics which led Hesiod to adapt the metre and diction of Homer to his own matter" ${ }^{42}$, we should now

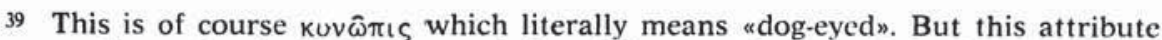
cannot refer to the physical characteristics of the eyes in view of the fact that often women so called are evidently beautiful as Helen in this case (cf. the Trojan Elders' reaction, Il. III $156 \mathrm{ff}$.) or even Aphrodite in Il. III $319 \mathrm{ff}$. who is a kuv

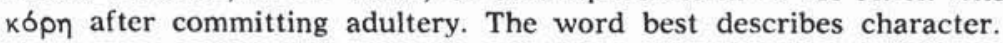

40 G. P. Edwards, op. cit., p. 101. In this context see also A. Hoekstra, «Hésiode et la tradition orale», Mnemosyne 10,1957, p. $193 \mathrm{ff}$.

41 For a recent discussion see my study (n. 20 above).

42 J. A. Thomson, A Companion to Homer (ed. Wace-Stubbings, London 1962), p. 4.
} 
add that Hesiod also adapted religious accounts of Homer for the same reason.

It may not be necessary for us to assume that the information about the gods participating in the creation of Pandora is derived from the Iliad or the Odyssey, but the incompleteness of the same information in Hesiod is best explained in terms of a background knowledge of the Homeric epics on the part of the poet's listeners. The epics themselves contain a similar kind of incomplete information which also presupposes knowledge of pre-Homeric poetry. A case in point is the vague introduction of, and some references to, the dramatis personae most of which figured in traditional poetry ${ }^{43}$. But even the composition of the Iliad, for example, can be better understood against the background of a chronicle type of narrative poetry ${ }^{44}$. Homer's technique of composition ${ }^{45}$ did not favor inclusion of all details of traditional stories.

Homer need not be the source of information for Hesiod and his listeners but then there must be some other major poetry which supplied the poet and his audience with the kind of information that is omitted from his work. Such poetry did not, to our knowledge, exist before Hesiod, unless one thinks of the inferior Cyclic epics or some of them. We know next to nothing about the date of these epics but the linguistic evidence and other considerations point to a post Homeric date ${ }^{46}$. The poetic "stuff" of the Cyclic epics is for the most part traditional; it antedates the composition of the Homeric epics, and it is apparently this "stuff" that informed listeners about much of what Homer did not tell. The same "stuff" might still, at a later age, be in circulation, but I should think that it were the specific compositions rather than the fluctuating "stuff" which was the source of information since such compositions would be considered the official and most authoritative accounts of the past.

It is difficult to establish what account exactly Hesiod presupposed for his listeners, and the absence, on the other hand, of a text of the

\footnotetext{
43 In this context see my study, Form and Content in Homer, Wiesbaden 1982 (Hermes Einzelschriften 46), passim.

44 Cf. W. Kullmann, "Zur Methode der Neoanalyse in der Homerforschung", WS $15 \mathrm{NF}, 1981$, p. 42.

45 Cf. Aristotle, Poetics 1451 a 21-26, and my paper, Phoenix 22, 1968, p. $159 \mathrm{ff}$.

46 Cf. J. Wackernagel, Sprachliche Untersuchungen zu Homer, Göttingen 1916, p. $181 \mathrm{ff.;}$ J. Griffin, "The Epic Cycle and the Uniqueness of Homer", JHS 97, 1977, p. 48; H. Lloyd-Jones, "Stasinus and the Cypria», Stasinos 4,1968, p. 119 . On the influence of the Homeric epics on some fragments of the Cyclic epics see Griffin (loc. cit., p. $42 \mathrm{ff}$.), G. L. Huxley, Greek Epic Poetry, London 1969, p. $128 \mathrm{ff}$. and,

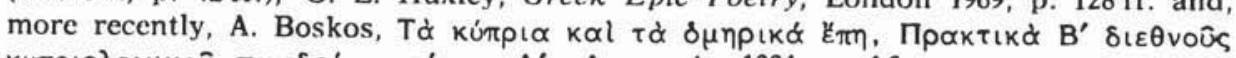

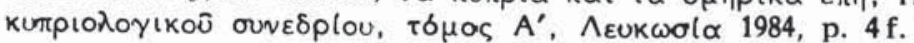


Cyclic epics ${ }^{47}$ makes a discussion of the question even more difficult. As it is, the presentation of the gods in the two poets indicates that chronologically Hesiod follows Homer. To assume that Hesiod preceds the Homeric epics, would require that we also assume that another complete and authoritative treatment of the gods preceds Hesiod. Nothing is known about such a treatment that might be important enough to influence Hesiod and his listeners. We know, on the other hand, that organized guilds were promoting the poems of Homer ${ }^{48}$.

It might be added, in support of the above argument, that Hesiod omits still other important details from the presentation of traditional personages elsewhere in his poetry. So, for example, in fr. $198^{49}$ Odysseus

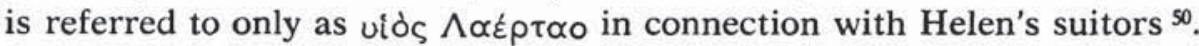
The poet undoubtedly assumed that his listeners were familiar with genealogical and other details of those heroes, which could only come from heroic poetry of a high rank. However, in some other way Hesiod completes Homer. So he tells us, for example, more about Scylla (fr. 262) than Od. XII $85 \mathrm{ff}$. does and more about Mycene (fr. 246) than Od. II 120. This is of course in line with his genealogical interests.

II

The above discussion has indicated that the Homeric epics provided the kind of background which enhanced the understanding of the role assigned to individual gods and goddesses in the creation of Pandora and that Hesiod assumed this background on the part of his listeners ${ }^{51}$. Hesiod might have other reasons for omitting this background from his presentation ${ }^{52}$, but I think that the chief reason lies in his listeners' acquaintance with the Homeric epics. Without the listeners' knowledge

47 As is well known, we depend, for our knowledge of those epics, upon later sources which were subject to a number of influences. In this context cf. $\varnothing$. Andersen, "Thersites und Thoas vor Troja", SO 57, 1982, p. $7 \mathrm{ff}$.

48 On the so-called Homeridae see A. Lesky, RE Suppl. XI, 1968, 690, $67 \mathrm{ff}$.

49 R. Merkelbach-M. L. West, Fragmenta Hesiodea, Oxford 1967, p. 97.

50 See further fr. 204 (Merkelbach-West, p. 100) for Idomeneus.

51 Note in this context that only the involvement of Peitho and the Horai (cf. vv. 73-75) seems to be left a little vague.

52 We should not forget that Hesiod treated mythological accounts in a critical spirit and that he professed to tell the truth (on this point recently, Neitzel, op. cit. p. $5 \mathrm{ff}$.). For this reason Hesiod might have decided not to include all traditional information about the gods or about some of them (e. g. about Hermes being a "thief" and a «trickster»). But if he considered that «information» or part of it to be «lies", he certainly did not stop from using it in the Pandora myth by presenting the gods along traditional lines. 
of those aspects of the nature and functions of the gods the description of Pandora would be confusing - to say the least. If the modern reader understands it, it is mainly because he knows Homer.

Aside from the main consideration discussed above, we find that the qualities of Pandora and the shortcomings of women in general are best understood in light of the Homeric epics. As already indicated, Hesiod's listeners would judge his poetry not so much by their personal experiences as by certain literary standards. They had of course their own ideas about women just as Hesiod had his, but women figured in poems composed by earlier generations of poets. Consciously or unconsciously the listeners would compare various poetic accounts of women's faults or virtues, and they would thus learn to appreciate the message of their poet.

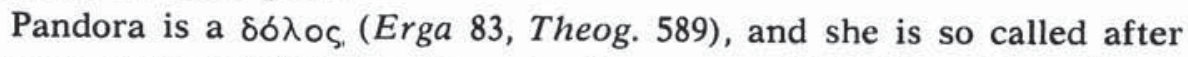
she has been created by the gods. I am sure that Hesiod's audience well understood the general meaning of the term which is strengthened

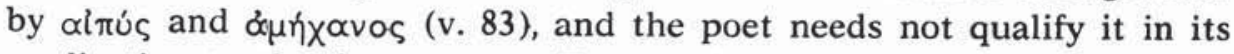
application to the first woman. But would Hesiod's audience interpret the word in the light of their personal experiences or in the light of any relevant poetic accounts? Moreover, what would Hesiod assume on their part?

The Homeric epics show several instances of feminine $\delta \delta \lambda \circ \varsigma$, and

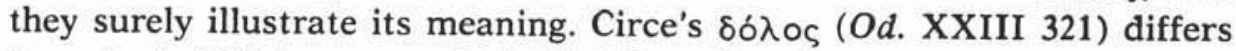
from that of Clytemnestra (Od. XI 439) as Hera's $\delta \delta \lambda \circ \varsigma$ differs from both of them (Il. XIV 197ff.). But even a virtuous woman like Penelope ${ }^{53}$ is endowed with $\delta o ́ \lambda \circ \varsigma$ (Od. XIX 137ff.). Pandora is a $\delta \delta \lambda_{\circ} \circ$, but if listeners were familiar with the feminine $\delta \delta \lambda \circ \varsigma$ in Homer, they would probably conclude that she was not meant to be all bad despite the emphasis on the kakóv of her nature (v. 88). In fact the poet does not think that women are all bad (Theog. 609f., Erga 405ff.). Yet it is the Odyssey which best illustrates feminine $\delta \delta \lambda$ os and people's reactions to it ${ }^{54}$.

In referring to the weaknesses of women outside the Pandora myth Hesiod also seems to assume that the listeners are familiar with the Homeric epics; hence the apparent lack of elaboration or comment, notwithstanding the proverbial style of some utterances. In Erga 327329 the poet says: $445 \mathrm{f}$.

53 Cf. for example Agamemnon's (i. e. his ghost's) praise of her in $\mathrm{Od}$. XI

54 Note also that the $\alpha$ l $\mu$ ú $\lambda$ เo $\lambda \delta$ yor with which Pandora is endowed (v. 78) has its Homeric parallel: in Od. I 56 the words are applied to Calypso. But Hesiod

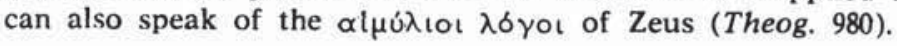




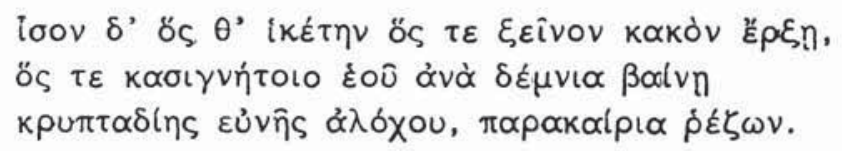

$\mathrm{He}$ condemns adultery when committed by relatives ${ }^{55}$ and compares the offence to that of the maltreatment of a suppliant or a stranger. But he has not stated how serious a crime the maltreatment of suppliants and strangers is. Does he not take it for granted that his listeners understand what he means and that they are familiar with well known cases? It is the Homeric poems, especially the Odyssey, which deal with this question and supply memorable examples ${ }^{56}$.

Next there is nothing to enlighten the audience about the consequences of the offence, after its seriousness has been underlined, and I think that the poet further assumes that his listeners are again familiar with the whole problem in the same sources. The most striking case of adultery involving relatives is described in Od. VIII 268ff. Ares and Aphrodite are the offenders:

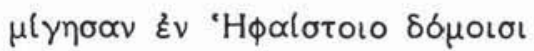

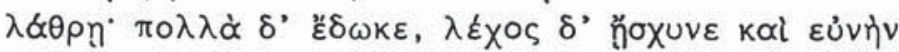

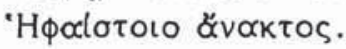

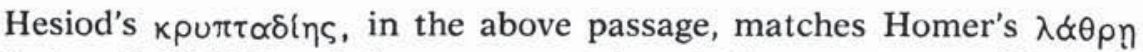
(269, also Il. VI 161) and the comment $\lambda \dot{\varepsilon} \chi \circ \delta^{\prime}$ ho $\sigma \chi \nu \varepsilon \varepsilon$ stresses Hesiod's outcry ${ }^{57}$. More importantly however, the Odyssean passage hints at the consequences of the offence which involve, among other things, financial settlements (318f.) and which would add to the problems of the Boeotian peasant in Hesiod's time.

It is not only adultery which the Homeric background elucidates for Hesiod's listeners ${ }^{58}$. There is also deceit. Hesiod advises (Erga $372-$ 375):

55 We should remember that Hesiod is primarily addressing himself to his brother Perses (Erga 10). Sinclair, op. cit., p. 36, seems to overlook the importance of this fact for the interpretation of the verses quoted above.

56 Cf. Il. III 351, XXIV 569 f., Od. XIII 213 f., XVI 412 ff., IX 270 ff., etc. For a recent discussion see my study, op. cit., p. $22 \mathrm{ff}$.

5 Cf. also $\alpha \tau \iota \mu \alpha \zeta \varepsilon \iota$ v. 309 which Hephaestus says of his wife Aphrodite. In $319 \mathrm{f}$. he refers to her as kuvêntı (cf. n. 39 above).

58 Cf. also Od. III $272 \mathrm{ff}$. where Nestor refers to Clytemnestra and Aegisthus. There are no explicit statements condemning this adultery. Vague and ominous

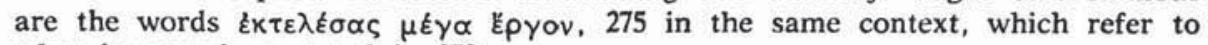
what happened as stated in 272. 


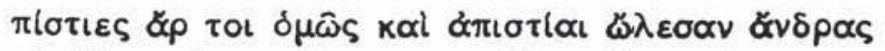

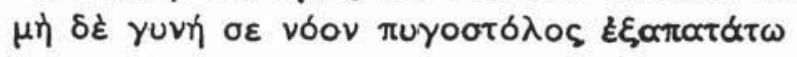

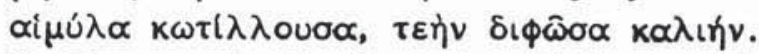

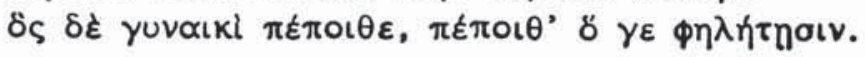

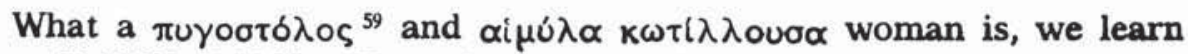
from $I l$. XIV 166-186 ${ }^{\circ}$. Here the poet details how Hera prepares herself to deceive her husband for her own advantage. She also lies to Aphrodite in the same context to enlist her help (198-210), and this is «wily

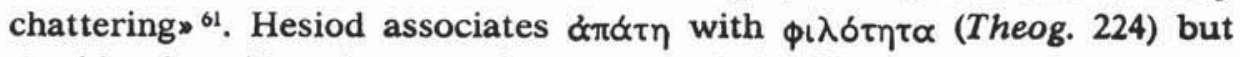
the idea is evident in several passages of the Homeric epics ${ }^{62}$.

If in Hesiod the woman is after a man's barn, which is understandable from the viewpoint of a farmer poet, in Homer she is after other things equally important ${ }^{63}$. The message is the same: «fix up your rump» for more effective results. Hence Hesiod's advice to fellow man: women are not to be trusted (375). But the Odyssey makes the same point

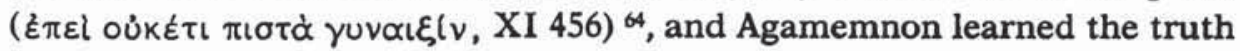
about his wife's falsehoods. I would say that Hesiod alludes to some

59 On this word see H. Frisk, op. cit., and the views quoted by Sinclair (op. cit., p. 40) and West, Erga 251.

60 The relationship between the Dios Apate, where the above quoted words belong, and Hesiod's Theogony has been discussed, and while some think mainly on linguistic grounds that the composer of the Apate had Hesiod in mind (cf. F. Schwenn, Die Theogonie des Hesiodos, Heidelberg 1934, p. 72 ff.), others are not convinced by the argument (cf. F. Solmsen, Hesiod and Aeschylus, New York 1949, p. $11 \mathrm{ff}$.). For criticism of Schwenn's «criteria» see Neitzel, op. cit., p. $6 \mathrm{ff}$.

61 In the same context we are reminded of Hera's previous machinations (249-

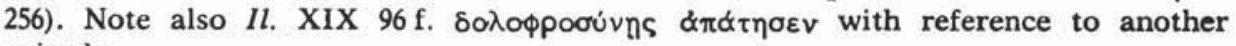
episode.

62 Cf. first $O d$. XV $420 \mathrm{ff}$. where the weakness of the female is attributed to love and sex. In $I l$. VI $160 \mathrm{ff}$. Anteia's unrequited desire for Bellerophon led her to make false accusations. Cf. further Od. XXIII 219 with reference to Helen's adultery and XVIII $321 \mathrm{ff}$. Melantho's affair with Eurymachus.

63 Yet the idea that women may set their minds upon seizing a man's property and possessions is not entirely absent from tho Odyssey. In XV $10 \mathrm{ff}$. the disguised Athena advises Telemachus to go home before his mother carries off his possessions (v. 19); he is supposed to know the kind of mind women have: olo $\theta \alpha \gamma \alpha \rho$

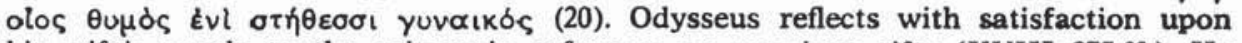
his wife's words to the suitors in reference to marriage gifts (XVIII $275 \mathrm{ff}$.). He applauds his wife's ruse to get presents from the suitors while she is not intending to marry anyone of them (282-283):

$$
\begin{aligned}
& \text { Һै }
\end{aligned}
$$

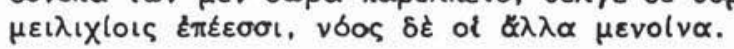

64 Such passages are considered late additions. Some argue that they reflect a hostile attitude towards women which best belongs to the time of the rising demos and the curtailment of women's rights. Cf. A. Jenzer, op. cit., p. $46 \mathrm{f}$. Cf. also Vogt, op. cit., p. 217.

LIV, $2.0-2$ 


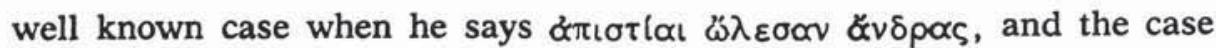
might very well be the death of Agamemnon as it is told in the Odyssey. Listeners would interpret this statement in the light of other poetic accounts though I am sure that they would also reflect on personal experiences. Above all, they were listening to poetry which was not exactly a record of people's experiences though poetry was rooted in social life ${ }^{\text {ss. }}$.

The above discussion has sufficiently indicated that in his treatment of an important theme ${ }^{\infty}$, Hesiod took into consideration his listeners' general knowledge of the Homeric epics with which he was of course acquainted himself ${ }^{67}$. Those who find misogynistic tendencies in some parts of the Odyssey believe that they belong to the time of the polis ${ }^{68}$, but the argument presented above is not affected by this view aside from whether a «late» Homeric passage is necessarily later than Hesiod.

\section{OdysSEUS TSAgarakis}

65 In this context see my study Self-Expression in Early Greek Lyric Elegiac and Iambic Poetry (Palingenesia XI), Wiesbaden 1977, p. $10 \mathrm{ff}$. and $148 \mathrm{ff}$.

66 Occasional remarks or statements on some good qualities of women might appear more illuminating if seen against the Homeric background. For example,

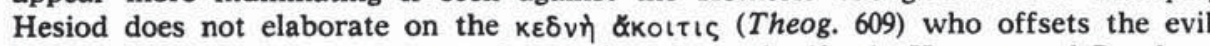
for man. There are enough examples of the «devoted wife» in Homer, and Penelope first comes to mind. In this context cf. Od. I 432, XXII 223.

67 In this context cf. p. 194, n. 28 above. In what state Hesiod and his listeners knew the Homeric epics, we do not know. Solmsen thinks, op. cit., p. 6, that «a good part of the Odyssey may not yet have existed when he composed his Theogony".

68 Cf. n. 60 above. But even in earlier parts of the poems some passages seem

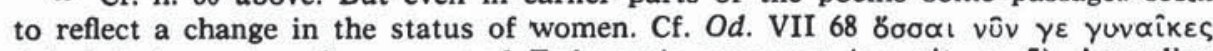

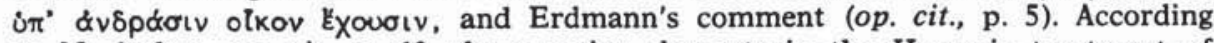
to M. Arthur, op. cit., p. 19, the negative elements in the Homeric treatment of women look forward in the status of women in the polis. The generally accepted view is of course that the Homeric epics reflect Bronze Age and Dark Ages attitudes, while Hesiod's reflect those of the early Archaic society. 